\title{
Antibacterial Activity of Lavandula mairei Humbert Essential Oil Against Carbapenem-resistant Acinetobacter baumannii
}

\author{
Lavandula mairei Humbert Esansiyel Yağının Karbapenem Dirençli Acinetobacter baumannii'ye \\ Karşı Antibakteriyel Aktivitesi
}

\author{
(D) Asma LAKTIB ${ }^{1}$, (D) Kaotar NAYME², (D) Abdellah El HAMDAOUI ${ }^{3}$, (D Mohammed TIMINOUNI ${ }^{2}$, (D Mohammed HASSI ${ }^{1}$, \\ (D) Aicha AIT ALLA ${ }^{1,4}$, (D) Fouad MSANDA ${ }^{3}$, (D) Mohammed BOUROUACHE ${ }^{1}$, (D) Mohamed El YAAGOUBI ${ }^{3}$, (D) Rachida MIMOUNI ${ }^{1}$, \\ (D) Brahim BIHADASSEN ${ }^{1}$, (D) Fatima HAMADI ${ }^{1}$ \\ 1 lbn Zohr University Faculty of Sciences, Laboratory of Microbial Biotechnology and Plants Protection, Agadir-Morocco, North Africa \\ 2 Pasteur Institute, Laboratory of Molecular Microbiology, Morocco, North Africa \\ $3 \mathrm{lbn}$ Zohr University Faculty of Sciences, Laboratory of Biotechnologies and Valorization of Natural Resources, Agadir-Morocco, North Africa \\ 4 Ibn Zohr University Faculty of Sciences, Laboratory Aquatic Systems: Marine and Continental Ecosystems, Agadir-Morocco, North Africa
}

\section{Abstract}

Introduction: Nosocomial infections associated with a carbapenem-resistant Acinetobacter baumannii (CRAB) are considered as a significant challenge in the Intensive care units' (ICU) critically ill patients. Lack of new antimicrobial agents to treat infections caused by this multi-drug resistant microorganism reinforces the exploration of novel strategies to encounter and control this infection. Thus, the aim of the study was to evaluate, for the first time, the antibacterial effectiveness of the Lavandula mairei Humbert essential oil (EO) against a CRAB isolated from the hospital environment of the two ICUs.

Materials and Methods: Carbapenemase encoding genes were detected by the polymerase chain reactions and sequencing methods. The chemical composition of Lavandula mairei (EO) was determined by a gas chromatography-mass spectrometry analysis, and its antibacterial activity was evaluated by a disk diffusion and broth microdilution methods.

Results: The OXA-23 and NDM-1 variants were revealed in the selected strains. Twenty-six compounds were identified in the Lavandula mairei E0, in which carvacrol was the most dominant one (77.32\%). All the tested CRAB strains showed a wide sensitivity to the oil, with the inhibition zones' diameters ranging from $28.67 \pm 1.15 \mathrm{~mm}$ to $40 \pm 2.00 \mathrm{~mm}$, and a bactericidal effect proved by the similarity of minimal inhibitory and bactericidal concentrations values $(0.39-3.125 \mu \mathrm{L} / \mathrm{ml})$.

Conclusion: These findings remain very promising for the future use of Lavandula mairei EO as a source of the natural antibacterial agents. Keywords: Antibacterial activity, carbapenem-resistant Acinetobacter baumannii, essential oils, Lavandula mairei Humbert, nosocomial infections 
Giriş: Karbapenem dirençli Acinetobacter baumannii ile ilişkili hastane enfeksiyonları, yoğun bakım ünitelerinde yatan kritik hastalarda önemli bir sorun olarak kabul edilmektedir. Bu çok ilaca dirençli mikroorganizmanın neden olduğu enfeksiyonları tedavi etmek için yeni antimikrobiyal ajanların olmaması, bu tür enfeksiyonlarla mücadele etmek için yeni stratejilerin araştırılmasını teşvik etmektedir. Bu nedenle, bu çalışmanın amacı, iki yoğun bakım ünitesinden izole edilen karbapenem dirençli Acinetobacter baumannii’ye karşı Lavandula mairei Humbert esansiyel yağının antibakteriyel etkinliğini ilk kez değerlendirmektir.

Gereç ve Yöntem: Karbapenemaz kodlayan genler, polimeraz zincir reaksiyonu ve dizileme yöntemleri ile tespit edildi. Lavandula mairei esansiyel yağının kimyasal bileşimi gaz kromatografisi-kütle spektrometrisi analizi ile belirlendi ve antibakteriyel aktivitesi disk difüzyon ve et suyu mikrodilüsyon yöntemleri ile değerlendirildi.

Bulgular: Seçilen suşlarda OXA-23 ve NDM-1 varyantları ortaya çıktı. Lavandula mairei esansiyel yağında, karvakrolün en baskın olduğu (\%77,32)

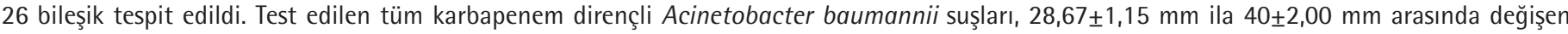
inhibisyon bölgelerinin çapları ile yağa karşı geniş bir duyarlılık gösterdi ve minimum inhibitör ve bakterisidal konsantrasyon değerlerinin benzerliği ile $(0,39$ ila $3,125 \mu \mathrm{L} / \mathrm{ml})$ kanıtlanmış bir bakterisidal etki gösterdi.

Sonuç: Bu bulgular, doğal antibakteriyel ajanların kaynağı olarak Lavandula mairei esansiyel yağının gelecekteki kullanımı için çok umut verici olmaya devam etmektedir.

Anahtar Kelimeler: Antibakteriyel aktivite, karbapenem dirençli Acinetobacter baumannii, esansiyel yağlar, Lavandula mairei Humbert, hastane enfeksiyonları

\section{Introduction}

Acinetobacterbaumannii (A. baumannii) is a Gram-negative nonmotile and non-fermentative coccobacilli usually encountered in the hospital environment, especially in the intensive care units (ICUs). It is incriminated in serious nosocomial infections (NIs) including bacteremia, ventilator-associated pneumonia, central nervous system, and urinary tract infections ${ }^{[1]}$.

Because of the anarchic and irrational antibiotic therapies, $A$. baumannii has rapidly emerged as multidrug-resistant (MDR) in healthcare facilities ${ }^{[2]}$. Multidrug-resistant $A$. baumannii (MRAB) is defined as a resistant to three or more groups of antibiotics (aminoglycosides, carbapenems, cephalosporins, and quinolones $)^{[3]}$. Numerous studies proved its wild prevalence in the hospital environment ${ }^{[4-6]}$, leading to the limited treatment options.

Carbapenems are known as the broad-spectrum antibiotics of a beta-lactam family, and the last resort to treat the antibiotic resistant infections. However, the worldwide dissemination of a carbapenem-resistant $A$. baumannii (CRAB) strains made them common and vulnerable ${ }^{[7,8]}$. Since carbapenems are the treatment of choice for $A$. baumannii infections, the carbapenem resistance, itself, is sufficient to consider CRAB as an extremely resistant ${ }^{[0]}$. In 2017, the World Health Organization underlined the threat of the CRAB to modern medicine as the first concern among a published list of 12 antibiotic resistant bacteria ${ }^{[0]}$.

Considering the therapeutic failures associated with the emergence of MDR bacteria (e.g., CRAB), several studies have focused on the research of alternative drugs especially based on the phytomedicine $e^{[11-13]}$. Since ancient times, plants and their derivatives such as essential oils (EOs) have been used in the traditional medicine worldwide. The antibacterial activity of the plant's EOs against the MDR pathogens has been evaluated by many investigations ${ }^{[11,14-16]}$.

Lavandula L. (Lamiaceae) is an old-world genus, and one of the most economically important members of the flowering plants of Lamiaceae family. It comprises about thirty-nine species, numerous hybrids, and about 400 registered cultivars ${ }^{[17]}$. Native to the Mediterranean region, Lavandula is largely distributed and cultivated in Europe, Canary Islands, Madeira, North Africa, Southwest Asia, Arabian Peninsula, India, North and South America ${ }^{[18]}$. The EOs of several Lavandula species are widely used in the aromatherapy with the significant antioxidant, antimicrobial, anti-inflammatory, spasmolytic, and carminative effects $^{[18-20]}$.

In Morocco, nine species and subspecies are identified in the genus of Lavandula, and in which, five are endemic ${ }^{[21]}$. Lavandula mairei (L. mairei) is one of these endemic species and it is considered as rare ${ }^{[22]}$. The wild plant is a perennial shrub with the spike violet flowers growing in Saharian, arid, and semi-arid bioclimates, from the southeast to the southwest mountains of Morocco ${ }^{[21]}$. This rare plant is mostly used in the traditional medicine for the treatment of gastrointestinal ailments, lung disorders, microbial infections, cough, asthma, headache, and fever ${ }^{[23]}$.

Therefore, we have conducted a study to evaluate the antibacterial activity of $L$. mairei EO against the CRAB isolated from the hospital environment of two ICUs (adult ICU and neonatal ICU) of the Regional Hospital Center of AgadirMorocco (RHCA).

To the best of our knowledge, there has been no previous report found investigating the antibacterial properties of L. mairei EO against the CRAB. 


\section{Materials and Methods}

\section{Molecular Identification of $A$. baumannii Strains}

The studied A. baumannii strains were isolated from the surfaces and medical equipment of two ICUs of the RHCA. These latter were subjected to a molecular identification by the amplification and sequencing of the 165 ribosomal RNA (16S rRNA) gene. The DNA extraction from the bacterial isolates was performed by a standard DNA extracted KIT (Isolate II Genomic DNA Kit, Bioline), according to the manufacturer's instructions. The amplification of the 16S rRNA gene was carried out in a DNA thermal cycler (Veriti, Applied Biosystems), with the following cycling program: Initial denaturation at 95 ${ }^{\circ} \mathrm{C}$ for $2 \mathrm{~min}$, and 35 cycles of denaturation at $95{ }^{\circ} \mathrm{C}$ for 30 sec annealing at $52{ }^{\circ} \mathrm{C}$ for $30 \mathrm{sec}$, extension at $72{ }^{\circ} \mathrm{C}$ for 30 sec, and a final extension at $72{ }^{\circ} \mathrm{C}$ for 3 min using the universal primer sequences ${ }^{[24,25]}$; fD1: 5'- AGAGTTGATCCTGGCTCAG3'and rP2: 5'-TACGGCTACCTTGTTACGACTT- 3. The sequencing of polymerase chain reactions (PCR) products was performed on an ABI 3130 XL sequencing apparatus (ABI 3130 XL Genetic Analyzer, Applied Biosystems). The acquired sequences were analyzed with the software available from the National Center for Biotechnology Information (www.ncbi.nlm.nih.gov).

\section{Antibiotic Susceptibility Testing of A. baumannii Strains}

The disc diffusion method on Mueller-Hinton Agar (MHA) was performed for an antibiotic susceptibility testing ${ }^{[26]}$. The following antibiotics were used for the test are: piperacillintazobactam $(30 \mu \mathrm{g})$, cefotaxime $(30 \mu \mathrm{g})$, ceftriaxone $(30 \mu \mathrm{g})$, ceftazidime $(30 \mu \mathrm{g})$, imipenem (IMP) $(10 \mu \mathrm{g})$, amikacin (AK) (30 $\mu \mathrm{g})$, gentamicin $(10 \mu \mathrm{g})$, ciprofloxacin $(5 \mu \mathrm{g})$, trimethoprimsulfamethoxazole (1.25 $\mu \mathrm{g}$-23.75 $\mu \mathrm{g})$, meropenem (MEM) $(10 \mu \mathrm{g})$, tetracycline $(\mathrm{T})(30 \mu \mathrm{g})$. The results were interpreted conforming to the guidelines of the Antibiogram Committee of the French Society for Microbiology ${ }^{[27]}$.

\section{Molecular Characterization of Carbapenem Resistance Genes}

\section{Preparation of DNA Template for PCR}

Overnight cultures of CRAB strains on Luria Bertani agar (Bio Rad) were subjected to a DNA extraction using the PureLink ${ }^{\circ}$ Genomic, DNA Mini Kit (Invitrogen, Carlsbad, USA) conforming to the manufacturer's instructions. DNA extracts were used as a template for the PCRs. These DNAs were stocked at $-20{ }^{\circ} \mathrm{C}$ until the use.

\section{Detection of Carbapenemase Encoding Genes}

The carbapenemase genes were assessed by a single PCR using the specific primers as previously described ${ }^{[28-32]}$ to identify: $\mathrm{bla}_{\mathrm{NDM}^{\prime}} \mathrm{bla}_{\text {OXA-23 }} \mathrm{bla}_{\text {OXA-24' }} \mathrm{bla}_{\text {OXA-58 }} \mathrm{bla}_{\mathrm{KPC}^{\prime}} \mathrm{bla}_{\mathrm{VIM}}$ and bla $\mathrm{GES}_{\text {GES }}$ (Table 1 ).
Amplification reactions were performed in a final volume of 50 $\mu \mathrm{L}$ with $5 \mu \mathrm{L}$ of $1 \times$ PCR buffer (Promega, USA), 2 U MyTaq DNA polymerase (New England BioLabs Inc., Beverly, MA, USA), 100 $\mu \mathrm{M}$ of deoxynucleoside triphosphates (dNTPs) (Invitrogen, USA), $2.5 \mathrm{mmol} / \mu \mathrm{L}$ of $\mathrm{MgCL}_{2}$ (Promega, USA), $0.4 \mu \mathrm{M}$ of each primer (Integrated DNA Technologies, USA), and $2 \mu \mathrm{L}$ of extracted DNA. All the primers used in the PCRs are represented in Table 1.

The thermal cycling conditions of each reactions are the initial denaturation at $94^{\circ} \mathrm{C}$ for $5 \mathrm{~min}$, followed by the 30 cycles of denaturation $\left(94{ }^{\circ} \mathrm{C}\right.$ for $\left.1 \mathrm{~min}\right)$, annealing $\left(60^{\circ} \mathrm{C}\right.$ for $1 \mathrm{~min}$ for $\mathrm{bla}_{\mathrm{KPC}^{\prime}} \mathrm{bla}_{\mathrm{VIM}^{\prime}}$ and $\mathrm{bla}_{\mathrm{GES}}, 57^{\circ} \mathrm{C}$ for $1 \mathrm{~min}$ for $\mathrm{bla}_{\mathrm{NDM}}$ and $54^{\circ} \mathrm{C}$ for 40 sec for bla ${ }_{0 \times A-23}$ bla $_{0 \times A-24^{\prime}}$ and bla $\left.{ }_{\text {OXA-58 }}\right)$, extension $\left(72{ }^{\circ} \mathrm{C}\right.$ for $1 \mathrm{~min}$ for $\mathrm{bla}_{\mathrm{KPC}^{\prime}} \mathrm{bla}_{\mathrm{VIM}^{\prime}} \mathrm{bla}_{\mathrm{GES}}$, and $\mathrm{bla}_{\mathrm{NDM}},{ }^{\circ} \mathrm{C}$ for $50 \mathrm{sec}$ for bla $\mathrm{OXX}_{\mathrm{OA}-23}$ $\mathrm{bla}_{0 \times \mathrm{A}-24^{4}}$ and $\mathrm{bla}_{\mathrm{OXA-58}}$ ), and achieving with a final extension (72 ${ }^{\circ} \mathrm{C}$ for 7 min for bla $\mathrm{KPC}^{\prime} \mathrm{bla}_{\mathrm{VIM}^{\prime}} \mathrm{bla}_{\mathrm{GES}}$, and $\mathrm{bla}_{\mathrm{NDM}}, 2^{\circ} \mathrm{C}$ for 6 min for bla $_{\text {OXA-23 }}$ bla $_{\text {OXA-24, }}$ and bla ${ }_{\text {OXA-58 }}$.

The PCR amplicons were then analyzed by an electrophoresis in a $1 \%$ agarose gel containing ethidium bromide.

\section{Sequencing of Resistance Genes}

All the amplified products were sequenced to validate their identities. Both strands of the purified amplicons were sequenced with a genetic Analyzer 3130x1 sequencer (Applied Biosystems), using the same primers as used for a PCR amplification. Nucleotide sequences were analyzed with the software available from the National Center for Biotechnology Information (http:// www.ncbi.nlm.nih.gov).

\section{Plant Materials}

Aerial parts of the wild L. mairei were collected at flowering stage, in the end of May 2014, from the Tafraout village in the southwest of Morocco. The voucher specimens were deposited in the laboratory of Biotechnology and Valorization of Natural Resources, Faculty of Sciences, Ibn Zohr University, Agadir, Morocco, and referred as LM114. All the plants samples were air-dried in the shade and stored in dark at $4{ }^{\circ} \mathrm{C}$ until use.

Essential Oil's Extraction and Gas Chromatography/Mass Spectrometry Analysis

Dried aerial parts of the wild L. mairei were subjected to a hydro distillation for $3 \mathrm{~h}$ using a Clevenger apparatus. The obtained EO was dried over anhydrous sodium sulfate and stored in an amber bottle at $4{ }^{\circ} \mathrm{C}$ prior to the analysis. The chemical composition of the studied EO was revealed by a gas chromatography/mass spectrometry (GC/MS) analysis. It was carried out by using the Agilent GC/MSD system (Agilent Technologies 6890/5973) equipped with an Agilent $\mathrm{DB}_{5}$ MS capillary column $(30.0 \mathrm{~m} \times$ $0.25 \mathrm{~mm}$ ID $\times 0.25 \mathrm{~mm}$ film thickness) programmed from 60-46 ${ }^{\circ} \mathrm{C}$ at $3{ }^{\circ} \mathrm{C} / \mathrm{min}$. The helium (high purity) was used as a carrier gas at a constant linear velocity of $37 \mathrm{~cm} / \mathrm{s}$. The transfer line, 
ionization source and quadrupole temperatures were 280,230 , and $150{ }^{\circ} \mathrm{C}$, respectively, operating at $70 \mathrm{eV}$ ionization energy and scanning the $\mathrm{m} / \mathrm{z}$ range $41-450$. EO samples $(60 \mathrm{ml})$ were diluted with the acetone $(2 \mathrm{ml})$. The injection volume was 1 $\mathrm{ml}$, the split ratio was 1:50 and the injector temperature was $260{ }^{\circ} \mathrm{C}$. Identification of the individual components was based on: (i) comparison of their mass spectra with that of pure reference samples consulting the Wiley and NBS libraries (WILEY275 and NBS75K), and the compilation by Adams and Sparkman ${ }^{[33]}$ (ii) comparison of their retention indices on a $\mathrm{DB}_{5}$ (apolar, 5\% phenyl polysilphenylenesiloxane), calculated relative to the retention times of a series of C-9-C-24 n-alkanes, with a linear interpolation, with those of authentic compounds or the literature data ${ }^{[33]}$. For semi-quantitative purposes, the normalized peak area of each compound was used without any correction factors to establish the abundances.

\section{Antibacterial Activity Test}

\section{Disc Diffusion Method}

The qualitative evaluation of the antibacterial activity of the wild L. mairei EO was carried out using the disc diffusion method on $\mathrm{MHA}^{[26]}$. The results were determined by measuring the diameters of inhibition zones after the incubation at $37^{\circ} \mathrm{C}$ for $24 \mathrm{~h}$. Amikacin discs (30 $\mu \mathrm{g} / \mathrm{disc}$ ) were used as the positive controls. All the tests were performed in triplicate.

The EO activity is classified into four levels: not sensitive for diameters $<8 \mathrm{~mm}$; sensitive for diameters 9-14 mm; very sensitive for diameters 15-19 mm, and extremely sensitive for diameters $>20 \mathrm{~mm}^{[34]}$.
Determination of Minimal Inhibitory and Minimal Bactericidal Concentrations

The minimal inhibitory concentration (MIC) analysis was performed in the MHB via broth microdilution technique using the 96-well microtiter plates ${ }^{[35]}$, with some modifications. Briefly, the bacterial suspension was prepared from a fresh overnight culture and diluted in MHB into an approximately $10^{6} \mathrm{CFU} / \mathrm{ml}$. The EO was serially diluted in MHB with $4 \%(\mathrm{v} / \mathrm{v})$ of dimethylsulfoxide (DMSO) to give a final EO concentration in the medium ranging from $25-0.04 \mu \mathrm{L} / \mathrm{ml}$. Each plate was placed in a shaker and was incubated at $37^{\circ} \mathrm{C}$ for $24 \mathrm{~h}$. MHB added with the inoculum, and MHB with 4\% DMSO were used as the positive and negative controls, respectively. Following the incubation, $20 \mu \mathrm{L}$ of $20 \mathrm{mg} / \mathrm{ml}$ solution of TTC (2,3,5-triphenyl tetrazoliumchloride, Sigma) were added to each well and incubated at $37{ }^{\circ} \mathrm{C}$ for $15 \mathrm{~min}$. A pink-red coloration of the wells indicated a bacterial growth. The MIC is defined as the lowest antimicrobial concentration which prevented the visible growth $^{[36]}$. The MIC value was referred to the corresponding EO concentration of the well in which no pink-red coloration was observed.

The minimal bactericidal concentration (MBC) is the lowest concentration at which the inoculum viability is reduced up to $99.9 \%$ or no apparent growth occurred ${ }^{[37]}$. It was determined that by spreading $10 \mu \mathrm{L}$ from the wells with no color change in Tryptic-Soy agar ${ }^{[38]}$. The plates were then incubated at $37^{\circ} \mathrm{C}$ for $24 \mathrm{~h}$. All the tests were performed in triplicate.

\section{Statistical Analysis}

The data were submitted to a statistical treatment by the analysis of variance using the R software, version 3.16 (RStudio, Inc).

Table 1. Amplicon sizes and primers used for the detection of carbapenemase encoding genes

\begin{tabular}{|c|c|c|c|c|}
\hline Genes & Primers & Nucleotide sequences 5'-3' & Product size $(\mathrm{pb})$ & References \\
\hline \multirow[t]{2}{*}{$b / a_{N D M}$} & NDM (+) & AATGGAATTGCCAATATTATGC & \multirow{2}{*}{489} & \multirow{2}{*}{ [29] } \\
\hline & NDM (-) & CGAAAGTCAGTTGCGCTGTG & & \\
\hline \multirow{2}{*}{$b / a_{K P C}$} & $\mathrm{KPC}(+)$ & ATGTCACTGTATCGCCGTCT & \multirow{2}{*}{881} & \multirow{2}{*}{ [28] } \\
\hline & KPC (-) & ПТАСТGСССGTТGАСGСССА & & \\
\hline \multirow[t]{2}{*}{$b / a_{V I M}$} & VIM (+) & ААAGTTATGCCGCACTCACC & \multirow{2}{*}{865} & \multirow{2}{*}{ [30] } \\
\hline & $\operatorname{VIM}(-)$ & TGCAАCTTСАTGTTATGCCG & & \\
\hline \multirow[t]{2}{*}{$b / a_{G E S}$} & GES (+) & АTGCGCTTCАTTCACGCAC & \multirow{2}{*}{863} & \multirow{2}{*}{ [31] } \\
\hline & GES (-) & СTATTGTCCGTGCTCAGGA & & \\
\hline \multirow[t]{2}{*}{$b / a_{o x a-23}$} & OXA-23like $(+)$ & GATCGGATTGGAGAACCAGA & \multirow{2}{*}{501} & \multirow{2}{*}{ [32] } \\
\hline & OXA-23like (-) & АПTСТGАССGСАTТССАT & & \\
\hline \multirow{2}{*}{$b / a_{\text {oxa-24 }}$} & OXA-24like (+) & GGTTAGTTGGCCСССТАAA & \multirow{2}{*}{246} & \multirow{2}{*}{ [32] } \\
\hline & OXA-24like (-) & AGTTGAGCGAAAAGGGGATT & & \\
\hline \multirow[t]{2}{*}{$b / a_{o x a-58}$} & OXA-58like(+) & AAGTATTGGGGCTTGTGCTG & \multirow{2}{*}{599} & \multirow{2}{*}{ [32] } \\
\hline & OXA-58like(-) & ССССТСТGСGСТСТАСАТАС & & \\
\hline
\end{tabular}




\section{Results}

Identification and Antibiotic Susceptibility of A. baumannii Isolates

The molecular identity of the six A. baumanniistrains was proved by the BLAST analysis of the obtained 165 rDNA sequences, which showed a similarity of $99 \sim 100 \%$ to the $A$. baumannii strain AYO-241 (Accession No: MT559273.1), A. baumannii strain 2-2-1-10 (Accession No: JF919866.1), A. baumannii strain 7-2-10 (Accession No: JF919865.1).

The antibiotic susceptibility test revealed that the six studied strains of the $A$. baumannii exhibited a considerable resistance to B-lactams especially to the carbapenems (IMP and MEM) with a sensitivity to the aminoglycosides (Table 2). Moreover, a reduced susceptibility to the other antibiotic families (fluoroquinolones and sulfonamides) was showed, proving the MDR phenotype of the strains.

\section{Molecular Detection of Carbapenemase Encoding Genes}

The molecular identification of the carbapenemase genes by PCR-sequencing revealed the predominance of a bla ${ }_{0 \times A-23}$ among all the six $A$. baumannii strains. On one out of the six CRAB strains, the coexistence of $b a_{0 X A-23}$ and $b a_{N D M}$ was detected. The analysis of the DNA sequences identified OXA-23 and NDM-1 variants (Table 3 ).

\section{Chemical Composition of L. mairei EO}

Based on the dry weight, the yield of the EO extracted by a hydro distillation from the aerial parts of the plant was $1.00 \pm 0.26 \%$. The GC-MS analysis of the L. mairei EO revealed twenty-six identified compounds, representing $>98 \%$ of the oil composition (Table 4). The monoterpenes were the most omnipresent constituents (89.99\%), with the oxygenated monoterpenes as the major compounds (82.36\%). Sesquiterpenes were the less common ones with only 5.13\%. Moreover, carvacrol was found to be the principal constituent of the L. mairei EO with the $77.32 \%$ followed by a terpinolene (2.73\%), octen-3-ol (1.93\%), p-cymen-8-ol (1.91\%), cis-ß-ocimene (1.78\%), carvacrol methyl ether (1.67\%), and B-caryophyllene (1.41\%).

\section{Antibacterial Activity Test Results}

Conforming to the results summarized in the Tables 5, 6, all the targeted CRAB strains presented a wide sensitivity to the $L$. mairei $\mathrm{EO}$, with a significant difference $(\mathrm{p}<0.05)$ between the

Table 2. Antibiotic susceptibility of the six A. baumannii strains isolated from adult and neonatal intensive care units

\begin{tabular}{|c|c|c|c|c|c|c|c|c|c|c|c|}
\hline \multirow[t]{2}{*}{ Strains } & \multicolumn{11}{|c|}{ Antibiotic susceptibility } \\
\hline & TZP & CTX & CIP & CAZ & TS & IMP & MEM & $\mathrm{CN}$ & AK & $\mathbf{T}$ & CRO \\
\hline \multicolumn{12}{|c|}{ Adult intensive care unit } \\
\hline$A B 2$ & $\mathrm{R}$ & $\mathrm{R}$ & $\mathrm{R}$ & $\mathrm{R}$ & $\mathrm{R}$ & $\mathrm{R}$ & $\mathrm{R}$ & $\mathrm{R}$ & $\mathrm{S}$ & $\mathrm{R}$ & $\mathrm{R}$ \\
\hline$A B 3$ & $\mathrm{R}$ & $\mathrm{R}$ & $\mathrm{R}$ & $\mathrm{R}$ & $\mathrm{R}$ & $\mathrm{R}$ & $\mathrm{R}$ & $\mathrm{S}$ & $\mathrm{S}$ & $\mathrm{R}$ & $\mathrm{R}$ \\
\hline$A B 5$ & $\mathrm{R}$ & $\mathrm{R}$ & $\mathrm{R}$ & $\mathrm{R}$ & $\mathrm{R}$ & $\mathrm{R}$ & $\mathrm{R}$ & $\mathrm{S}$ & $\mathrm{S}$ & $\mathrm{R}$ & $\mathrm{R}$ \\
\hline \multicolumn{12}{|c|}{ Neonatal intensive care unit } \\
\hline$A B 6$ & $\mathrm{R}$ & $\mathrm{R}$ & $\mathrm{R}$ & $\mathrm{R}$ & $\mathrm{R}$ & $\mathrm{R}$ & $\mathrm{R}$ & $\mathrm{S}$ & $\mathrm{S}$ & $\mathrm{S}$ & $\mathrm{R}$ \\
\hline
\end{tabular}

Table 3. Carbapenemase encoding genes' detection of CRAB strains isolated from adult and neonatal intensive care units

\begin{tabular}{|c|c|c|c|c|c|c|c|c|}
\hline Strains & Cabapen & encoding & nes & & & & & Detected variants \\
\hline & bla $_{\text {OXA-23 }}$ & bla $_{\text {OXA-24 }}$ & $b^{\prime l a}{ }_{0 \times A-58}$ & bla $_{N D M}$ & bla $_{\text {GES }}$ & bla $_{K P C}$ & bla $_{V I M}$ & \\
\hline$A B 1$ & + & - & - & - & - & - & - & OXA-23 \\
\hline$A B 3$ & + & - & - & - & - & - & - & OXA-23 \\
\hline$A B 4$ & + & - & - & - & - & - & - & OXA-23 \\
\hline$A B 6$ & + & - & - & + & - & - & - & OXA-23/NDM-1 \\
\hline
\end{tabular}

(+): Presence; (-): Absence. 
tested strains. Indeed, the studied EO showed an antibacterial effect with the inhibition zones' diameters ranging from $40 \pm 2.00$ - 28.67 $\pm 1.15 \mathrm{~mm}$ (Table 5). Moreover, L. mairei EO revealed higher antibacterial properties than the positive control (AK), considered as an extended spectrum antibiotic. For the broth microdilution assay, the results are given in the Table 6. The EO inhibited the CRAB strains at concentrations varying from 0.39$3.125 \mu \mathrm{L} / \mathrm{ml}$. It is important to mention the MBC and MIC values were equivalent for all tested strains, proving the bactericidal effect of the L. mairei EO (Table 6).

Table 4. Chemical composition of L. mairei essential oil

\begin{tabular}{|c|c|c|c|}
\hline Compounds* & $\mathrm{M}+($ Parent lon $)$ ** & $\mathrm{RI}^{* * *}$ & $\%$ of compound \\
\hline$\alpha$-pinene & 136 & 931 & 0.35 \\
\hline Octen-3-ol & 128 & 972 & 1.93 \\
\hline Octan-3-one & 128 & 984 & 0.46 \\
\hline$\beta$-Myrcene & 136 & 990 & 0.79 \\
\hline Octan 3-ol & 136 & 996 & 0.33 \\
\hline$\alpha$-Phellandrene & 136 & 1008 & 0.15 \\
\hline$d$-3-Carene & 136 & 1012 & 0.51 \\
\hline$\alpha$-Terpinene & 136 & 1016 & 0.14 \\
\hline p-Cymene & 132 & 1021 & 0.75 \\
\hline Limonene & 136 & 1025 & 0.29 \\
\hline Cis- $\beta$-Ocimene & 136 & 1042 & 1.78 \\
\hline Trans- $\beta$-Ocimene & 136 & 1051 & 0.14 \\
\hline Terpinolene & 136 & 1088 & 2.73 \\
\hline Linalool & 154 & 1096 & 0.33 \\
\hline Borneol & 154 & 1165 & 0,04 \\
\hline Mentha-1.8-dien-4-ol & 154 & 1177 & 0.29 \\
\hline Terpinen-4-ol & 154 & 1178 & 0.37 \\
\hline p-Cymen-8-ol & 150 & 1184 & 1.91 \\
\hline$\alpha$-Terpineol & 154 & 1191 & 0.43 \\
\hline Carvacrol methyl ether & 164 & 1244 & 1.67 \\
\hline Bornyl acetate & 150 & 1294 & 0.27 \\
\hline Carvacrol & 150 & 1302 & 77.32 \\
\hline$\beta$-Caryophyllene & 202 & 1424 & 1.41 \\
\hline Spathulenol & 224 & 1581 & 1.55 \\
\hline Caryophyllene oxide & 216 & 1587 & 2.17 \\
\hline Manoyloxide & 290 & 2036 & 0.45 \\
\hline
\end{tabular}

\section{Discussion}

The rapid emergence of the $A$. baumannii infections is posing a serious public health threat in the ICUs' immune-compromised patients. This microorganism is intrinsically resistant to a wide array of the antibiotics and may acquire an armamentarium of resistance mechanisms (efflux pumps, drug-inactivating enzymes, and the drug target mutations) that allow this pathogen to become easily resistant to almost or even all the convenient antimicrobial agents ${ }^{[39]}$. Due to their valuable activity and low

Monoterpene hydrocarbons: 7.63

Oxygenated monoterpens: 82.36

Sesquiterpene hydrocarbons: 1.41

Oxygenated sesquiterpens: 3.72

Oxygenated diterpenes: 0.45

Others: 2.99

Total: 98.56

*: Compounds listed in order of elution.

**: Ionization mode: electron impact at $70 \mathrm{eV}$.

***: Retention Indices measured relative to n-alkanes (C-9-C-24) on a nonpolar $\mathrm{DB}_{5}-\mathrm{MS}$ column. 
Table 5. Inhibition zone diameters of $L$. mairei essential oil and positive control against a carbapenem-resistant $A$. baumannii strains

\begin{tabular}{|c|c|c|}
\hline \multirow[t]{2}{*}{ Bacterial strains } & \multicolumn{2}{|c|}{ Inhibition zone diameters $(\mathrm{mm})$} \\
\hline & L. mairei EO & Amikacin (positive control) \\
\hline$A B 1$ & $32.50 \pm 2.00^{\mathrm{a}}$ & $22.00 \pm 0.00^{c}$ \\
\hline$A B 2$ & $40.00 \pm 2.00^{c}$ & $20.00 \pm 0.00^{b}$ \\
\hline$A B 3$ & $33.33 \pm 1.53^{\mathrm{ab}}$ & $21.00 \pm 0.00^{\mathrm{bc}}$ \\
\hline$A B 4$ & $31.60 \pm 3.05^{\mathrm{a}}$ & $21.33 \pm 0.57^{c}$ \\
\hline$A B 5$ & $38.00 \pm 0.00^{\mathrm{bc}}$ & $21.00 \pm 0.00^{\text {bc }}$ \\
\hline$A B 6$ & $28.67 \pm 1.15^{\mathrm{a}}$ & $17.00 \pm 1.00^{\mathrm{a}}$ \\
\hline
\end{tabular}

EO: Essential oil

Table 6. Inhibition zone diameters of $L$. mairei essential oil and positive control against a carbapenem-resistant $A$. baumannii strains

\begin{tabular}{lll}
\hline Bacterial strains & $C M I(\mu \mathrm{L} / \mathrm{ml})$ & $C M B(\mu \mathrm{L} / \mathrm{ml})$ \\
\hline$A B$ 1 & $1.56 \pm 0.00^{\mathrm{c}}$ & $1.56 \pm 0.00^{\mathrm{c}}$ \\
\hline$A B$ 2 & $0.78 \pm 0.00^{\mathrm{b}}$ & $0.78 \pm 0.00^{\mathrm{b}}$ \\
\hline$A B$ 3 & $0.78 \pm 0.00^{\mathrm{b}}$ & $0.78 \pm 0.00^{\mathrm{b}}$ \\
\hline$A B$ 4 & $3.125 \pm 0.00^{\mathrm{d}}$ & $3.125 \pm 0.00^{\mathrm{d}}$ \\
\hline$A B$ 5 & $0.39 \pm 0.00^{\mathrm{a}}$ & $0.39 \pm 0.00^{\mathrm{a}}$ \\
\hline$A B$ 6 & $0.78 \pm 0.00^{\mathrm{b}}$ & $0.78 \pm 0.00^{\mathrm{b}}$ \\
\hline
\end{tabular}

$a, b, c, d:$ Mean statistically significant differences with $p<0.05$.

EO: Essential oil

toxicity, carbapenems are recognized as the only appropriate treatment of infections caused by this microorganism. However, in the recent years, carbapenems resistance is increasingly common in the $A$. baumannii compromising this therapeutic option as well[40].

The six chosen strains for the current study were identified by the $16 S$ rRNA sequencing as A. baumannii with $99 \sim 100 \%$ of similarity. These identified strains revealed a great resistance to the several families of antibiotics including carbapenems (Table 2). Similarly, a study found that the A. baumanniistrains isolated from a hospital environment in Iran, showed a considerable resistance to the IMP (94\%) $)^{[41]}$. In another investigation carried out in the Mohammed V Military teaching hospital in RabatMorocco, a great resistant to the carbapenems (100\%) was manifested by $A$. baumannii isolates ${ }^{[42]}$. It should be noted that this region of Morocco (Rabat-Salé-Zemmour-Zaer) has known as a significant spread of CRAB in the healthcare facilities ranging from $23.6 \%$ in $2001^{[43]}$ to $76.19 \%$ in $2012-2014^{[44]}$.

The molecular characterization of the carbapenemase encoding genes confirmed the resistance patterns of the isolated strains. Indeed, bla ${ }_{\text {oxa-23 }}$ gene was detected in all the A. baumannii isolates (Table 3). The OXA-23 enzyme, a member of the Ambler class D group of the B-lactamases, could hydrolyze carbapenems with a slow activity against oxyimino cephalosporins, aminopenicillins, and oxacillin ${ }^{[45,46]}$. The genes encoding for these enzymes are especially related with the mobile genetic elements prompting their transmission to the other species ${ }^{[47]}$. Worldwide outbreaks of the infections due to $A$. baumannii strains carrying bla ${ }_{\text {oxa-23 }}$ have been documented by the previous investigations ${ }^{[48-51]}$. In a Moroccan study, most of the clinical and environmental CRAB $(69.6 \%)$ isolates presented bla ${ }_{\text {oxa-23 }}$ gene ${ }^{[51]}$.

In addition to the bla ${ }_{\text {oxa-23 }}$ gene, one strain (AB 6) of six of $A$. baumannii isolated in the current study harbored another carbapenemase gene: bla ${ }_{\mathrm{NDM}}$ commonly reported among Enterobacteriacea ${ }^{[52]}$. This coexistence maybe explained by the possible transmission of the resistance genes via a horizontal gene transfer ${ }^{[53]}$. This phenomenon was also found in the two isolated CRAB in Thailand ${ }^{[54]}$.

Therefore, finding the new chemical substances with efficient therapeutic effects to the combat MDR infections has become a necessity worldwide. EOs, a complex mixture of the secondary metabolites of aromatic and medicinal plants is known to be a potential source of natural active compounds ${ }^{[55]}$. 
In this study, among the identified compound of the extracted L. mairei EO, the phenol monoterpene carvacrol was the most dominant constituent (77.32\%) (Table 4). A study conducted to investigate the chemical composition of the L. multifida EO, revealed that the carvacrol was the main component with $61.73 \%{ }^{[56]}$. Likewise, findings of a report affirmed the predominance of carvacrol (42.6\%) in the L. canariensis (L.) Mill. EO ${ }^{[57]}$. On the contrary, other Lavandula species expressed lower concentrations of carvacrol or even the absence of the molecule ${ }^{[58,59]}$.

L. mairei EO exhibited a great antibacterial activity against all the tested strains of CRAB (Tables 5,6$)$. Indeed, the obtained results showed that the $\mathrm{MIC}$ and $\mathrm{MBC}$ values were identical $(\mathrm{MIC}=\mathrm{MBC}=0.39-3.125 \mu \mathrm{L} / \mathrm{ml})$, proving the bactericidal effect of the oil. In a literature survey, no study related to the antibacterial activity of the $L$. mairei EO against a carbapenemresistant nosocomial $A$. baumannii isolates has been reported. Thus, the obtained results could not be compared with the other studies. However, they were analyzed with some investigations conducted with the other aromatic and medicinal plants' species. It was underlined in a previous study that the considerable effect of the Moroccan $L$. coronopifolia on a clinical isolate of the MRAB with MIC and MBC values ranging between 1 and $2 \%{ }^{[60]}$. On other hand, an investigation concluded the bactericidal action $(\mathrm{MIC}=\mathrm{MBC}=0.31-0.62 \mathrm{mg} / \mathrm{ml}$ in most of the cases) of Satureja khuzestanica Jamzad EO on twenty-one MRAB strains ${ }^{[14]}$. The inhibition's growth of CRAB by Origanum vulgare L. essential has also been proved with a CMI of $0.015 \%$ $(\mathrm{v} / \mathrm{v})^{[61]}$.

The strong activity of the L. mairei EO could be associated with the presence of high concentrations of carvacrol (Table 4). Due to its hydrophobic nature, and the hydroxyl group present in its chemical structure, this constituent has a great effect on the membrane of the bacterial cells ${ }^{[55]}$. It causes the disintegration of the outer membrane of Gram-negative bacteria, compromising a series of critical functions, especially the energy for the conversion processes, nutrient processing, synthesis of the structural macromolecules, and of many growth key enzymes, eventually leading to the bacterial death ${ }^{[62]}$. The antibacterial activity of the carvacrol against CRAB has been confirmed by a previous work $^{[63]}$. The most promising antimicrobial activity results of the carvacrol were against three strains of A. baumannii that were MDR or extremely a drug resistant, positive for carbapenemase encoding genes ${ }^{[63]}$. However, considering the $\mathrm{EO}$ as a mixture of bioactive molecules, the main compound is not necessarily behind the whole antibacterial activity. The involvement of the other minor molecules should be considered ${ }^{[64,65]}$. These molecules could interact with each other or with the major active compounds. The inhibition effect may differ according to their interactive functions. Different mechanism of actions of one or several compounds could be involved, and thus acting at several sites of the cell[66].

The limitation of the study was the small number of $A$. baumannii isolates. It should be noted that among the A. baumannii strains isolated during the study conducted in the RHCA, the six chosen strains for the current study had the most relevant antibiotic patterns with a resistance to carbapenems.

\section{Conclusion}

For the first time, this study highlighted a significant antibacterial activity of $L$. mairei EO against the CRAB. All the tested bacteria presented $0 X A-23$ variant with coexistence between this latter and NDM-1 variant in one strain, proving their MDR and capacity to induce NIs difficult to treat. Thus, the obtained results are very encouraging, and suggest that this EO, rich in the carvacrol (77.32\%), is an eventual candidate for further studies to develop the alternative bioactive molecules or to include it in the formulations of some disinfectant and antiseptic solutions to reduce the cross contaminations in the hospital environment.

\section{Acknowledgments}

The authors are grateful to the Regional Hospital Center of Agadir, and all the medical staff of the adult and neonatal intensive care units for their collaboration. We also want to thank the Laboratory of Medical Analysis, and the team of the $\mathrm{NI}$ control committee of the RHCA. Our gratitude goes to the National Center of Scientific and Technical Research of Morocco for the molecular identification of the studied strains.

\section{Ethics}

Ethics Committee Approval: The study were approved by the Bioethics Consultative Commission Faculty of Sciences Agadir (protocol number: ER-BS-02/2022-0001, date: 27.02.2022).

Informed Consent: The strains studied were isolated from solid surfaces found in the hospital environment such as silicone, ceramics.

Peer-review: Externally peer-reviewed.

\section{Authorship Contributions}

Concept: A.A.A., F.H., M.H., R.M., F.M., B.B., Design: A.A.A., F.H., M.H., R.M., M.T., Data Collection or Processing: A.L., K.N., F.M., M.T., M.El Y., A.El H., Analysis or Interpretation: M.B., A.L., B.B., K.N., M.T., F.M., A.El H., M.El Y., Literature Search: A.L., K.N., M.B., B.B., M.El Y., Writing: A.L., M.H., F.H., R.M., A.A.A., B.B., A.El H.

Conflict of Interest: No conflict of interest was declared by the authors.

Financial Disclosure: The authors declared that this study received no financial support. 


\section{References}

1. Zarrilli R, Giannouli M, Tomasone F, Triassi M, Tsakris A. Carbapenem resistance in Acinetobacter baumannii: The molecular epidemic features of an emerging problem in health care facilities. J Infect Dev Ctries. 2009;3:335-41.

2. Maragakis LL, Perl TM. Acinetobacter baumannii: epidemiology, antimicrobial resistance, and treatment options. Clin Infect Dis. 2008;46:1254-63.

3. Jung J, Park W. Acinetobacter species as model microorganisms in environmental microbiology: current state and perspectives. Appl Microbiol Biotechnol. 2015;99:2533-48.

4. Kramer A, Schwebke I, Kampf G. How long do nosocomial pathogens persist on inanimate surfaces? A systematic review. BMC Infect Dis. 2006;6:130.

5. EL Bakkali $M$, Hmid K, Kari KE, Zouhdi M, Mzibri M, Laglaoui A. Characterization of Bacterial Strains and their Resistance Status in Hospital Environment. J Trop Dis. 2016;4:1-6.

6. Amiyare R, Afifi I, Ouhssine M. Hospital environment and risk of nosocomial infections in the intensive care unit of provincial hospital El Idrissi of Kenitra in Morocco. Der Pharm Lett. 2015;7:134-40.

7. Hamidian M, Nigro SJ. Emergence, molecular mechanisms and global spread of carbapenem-resistant Acinetobacter baumannii. Microb Genomics. 2019;5:e000306.

8. Peleg AY, Seifert H, Paterson DL. Acinetobacter baumannii: Emergence of a successful pathogen. Clin Microbiol Rev. 2008;21:538-82.

9. Kluytmans-Vandenbergh MFQ, Kluytmans JAJW, Voss A. Dutch guideline for preventing nosocomial transmission of highly resistant microorganisms (HRM0). Infection. 2005;33:309-13.

10. Shrivastava SR, Shrivastava PS, Ramasamy J. World Health Organization releases global priority list of antibiotic-resistant bacteria to guide research, discovery, and development of new antibiotics. J Med Soc. 2018;32:76-7.

11. Fadli M, Saad A, Sayadi S, Chevalier J, Mezrioui NE, Pagès JM, Hassani L. Antibacterial activity of Thymus maroccanus and Thymus broussonetii essential oils against nosocomial infection - Bacteria and their synergistic potential with antibiotics. Phytomedicine. 2012;19:464-71.

12. Valle DL, Andrade JI, Puzon JJM, Cabrera EC, Rivera WL. Antibacterial activities of ethanol extracts of Philippine medicinal plants against multidrug-resistant bacteria. Asian Pac J Trop Biomed. 2015;5:532-40.

13. Ibrahim MK, Mattar ZA, Abdel-Khalek HH, Azzam YM. Evaluation of antibacterial efficacy of anise wastes against some multidrug resistant bacterial isolates. J Radiat Res Appl Sci 2017;10:34-43.

14. Eftekhar F, Ashoori N, Yousefzadi M. In vitro Antimicrobial Activity and Chemical Composition of Satureja khuzestanica Jamzad Essential Oils Against Multidrug-Resistant Acinetobacter baumannii. Avicenna J Clin Microbiol Infect. 2017;4:45601.

15. Bučková M, Puškárová $A$, Kalászová V, Kisová Z, Pangallo D. Essential oils against multidrug resistant gram-negative bacteria. Biologia. 2018;73:8038.

16. Lu M, Dai T, Murray CK, Wu MX. Bactericidal property of oregano oil against multidrug-resistant clinical isolates. Front Microbiol. 2018;9:1-14.

17. Passalacqua NG, Tundis $R$, Upson TM. A new species of Lavandula sect. Lavandula (Lamiaceae) and review of species boundaries in Lavandula angustifolia. Phytotaxa. 2017;292:161-70.

18. Benabdelkader T, Zitouni A, Guitton $Y$, Jullien F, Maitre D, Casabianca $H$, Legendre L, Kameli A. Essential oils from wild populations of algerian Lavandula stoechas L.: Composition, chemical variability, and in vitro biological properties. Chem Biodivers. 2011;8:937-53.

19. Soulaimani B, Nafis A, Kasrati A, Rochdi A, Mezrioui NE, Abbad A, Hassani L. Chemical composition, antimicrobial activity and synergistic potential of essential oil from endemic Lavandula maroccana (Mill.). South African J Bot. 2019;125:202-6.

20. Ez Zoubi Y, Dalila, El Mansouri L, Boukhira S, Lebtar S, Sanae A, Farah A. Phytochemical screening, anti-inflammatory activity and acute toxicity of hydro-ethanolic, flavonoid, tannin and mucilage extracts of Lavandula stoechas L. from Morocco. Int J Pharmacogn Phytochem Res. 2016;8:31-7.

21. El Hamdaoui $A$, Msanda $F$, Boubaker $H$, Leach $D$, Bombarda I, Vanloot $P, E l$ Aouad N, Abbad A, Boudyach E H, Achemchem F, Elmoslih A, Ben Aoumar A, El Mousadik A. Essential oil composition, antioxidant and antibacterial activities of wild and cultivated Lavandula mairei Humbert. Biochem Syst Ecol. 2018;76:1-7.

22. Fennane M, Tattou MI. Catalogue des plantes vasculaires rares, menacées ou endémiques du Maroc. Bocconea, Palerme, 1998.

23. Abouri M, Mousadik A El, Msanda F, Boubaker H, Saadi B, Cherifi K. An ethnobotanical survey of medicinal plants used in the Tata Province, Morocco. Int J Med Plant Res. 2012;1:99-123.

24. Drancourt M, Bollet C, Carlioz A, Martelin R, Gayral JP, Raoult D. $16 \mathrm{~S}$ ribosomal DNA sequence analysis of a large collection of environmental and clinical unidentifiable bacterial isolates. J Clin Microbiol. 2000;38:3623-30.

25. Weisburg WG, Barns SM, Pelletier DA, Lane DJ. 16S ribosomal DNA amplification for phylogenetic study. J Bacteriol.1991;173:697-703.

26. Balouiri M, Sadiki M, Ibnsouda SK. Methods for in vitro evaluating antimicrobial activity: A review. J Pharm Anal. 2016;6:71-9.

27. Comité de l'Antibiogramme de la Société Française de Microbiologie (CASFM). Last accessed date: 2016 Jan 15. Available from: https://www.sfmmicrobiologie.org/

28. Maroui I, Barguigua A, Aboulkacem A, Ouarrak K, Sbiti M, Louzi H, Timinouni $\mathrm{M}$, Belhaj A. First report of VIM-2 metallo- $\beta$-lactamases producing Pseudomonas aeruginosa isolates in Morocco. J Infect Chemother. 2016;22:127-32

29. Tijet $N$, Alexander DC, Richardson D, Lastovetska O, Low DE, Patel SN, Melano RG. New Delhi metallo- $\beta$-lactamase, Ontario, Canada. Emerg Infect Dis. 2011;17:306-7.

30. Mendes RE, Castanheira M, Garcia P, Guzman M, Toleman MA, Walsh TR, Jones RN; SENTRY Antimicrobial Surveillance Program. First Isolation of blaVIM-2) in Latin America: Report from the SENTRY Antimicrobial Surveillance Program. Antimicrob. Agents Chemother. 2004;48:1433-4.

31. Poirel L, Nordmann P. Carbapenem resistance in Acinetobacter baumannii: Mechanisms and epidemiology. Clin Microbiol Infect. 2006;12:826-36.

32. Woodford $\mathrm{N}$, Ellington MJ, Coelho JM, Turton JF, Ward ME, Brown $\mathrm{S}$, Amyes SG, Livermore DM. Multiplex PCR for genes encoding prevalent OXA carbapenemases in Acinetobacter spp. Int J Antimicrob Agents. 2006;27:351-3.

33. Adams R, Sparkman 0. Review of Identification of Essential Oil Components by Gas Chromatography/Mass Spectrometry.4th ed. Allured Publishing Corp, Carol Stream, IL, 2007:469.

34. Ponce AG, Fritz R, Del Valle C, Roura SI. Antimicrobial activity of essential oils on the native microflora of organic Swiss chard. LWT-Food Sci Technol. 2003;36:679-84.

35. Bazargani MM, Rohloff J. Antibiofilm activity of essential oils and plant extracts against Staphylococcus aureus and Escherichia coli biofilms. Food Control. 2016;61:156-64.

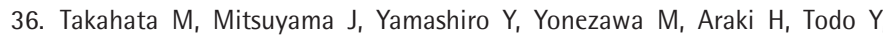
Minami $S$, Watanabe $Y$, Narita $\mathrm{H}$. In vitro and in vivo antimicrobial activities of T-3811ME, a novel des- F(6)-quinolone. Antimicrob Agents Chemother. 1999:43:1077-84

37. Moreira MR, Ponce AG, Del Valle CE, Roura SI. Inhibitory parameters of essential oils to reduce a foodborne pathogen. LWT Food Sci Technol. 2005;38:565-70. 
38. Hossain S, Heo H, De Silva BCJ, Wimalasena SHMP, Pathirana HNKS, Heo G. Antibacterial activity of essential oil from lavender (Lavandula angustifolia) against pet turtle-borne pathogenic bacteria. Lab Anim Res. 2017;33:195201.

39. Asif $M$, Alvi IA, Rehman SU. Insight into Acinetobacter baumannii: Pathogenesis, global resistance, mechanisms of resistance, treatment options, and alternative modalities. Infect Drug Resist. 2018;11:1249-60.

40. Evans BA, Hamouda A, Amyes SGB. The Rise of Carbapenem-Resistant Acinetobacter baumannii. Curr Pharm Des. 2013;19:223-38.

41. Tajeddin E, Rashidan M, Razaghi M, Javadi SS, Sherafat SJ, Alebouyeh M, Sarbazi MR, Mansouri N, Zali MR. The role of the intensive care unit environment and health-care workers in the transmission of bacteria associated with hospital acquired infections. J Infect Public Health. 2016;9:13-23

42. Uwingabiye J, Lemnouer $A$, Roca I, Alouane $T$, Frikh $M$, Belefquih $B$, Bssaibis F, Maleb A, Benlahlou Y, Kassouati J, Doghmi N, Bait A, Haimeur C, Louzi L, Ibrahimi A, Vila J, Elouennass M. Clonal diversity and detection of carbapenem resistance encoding genes among multidrug-resistant Acinetobacter baumannii isolates recovered from patients and environment in two intensive care units in a Moroccan hospital. Antimicrob Resist Infect Control. 2017;6:99.

43. Elouennas M, Bajou $T$, Lemnouer AH, Foissaud V, Hervé V, Baaj AJ. Acinetobacter baumannii: Étude de la sensibilité des souches isolées à I'hôpital militaire d'instruction Mohammed V, Rabat, Maroc. Med Mal Infect. 2003;33:361-4.

44. Uwingabiye J, Frikh $M$, Lemnouer $A$, Bssaibis $F$, Belefquih $B$, Maleb $A$, Dahraoui S, Belyamani L, Bait A, Haimeur C, Louzi L, Ibrahimi A, Elouennass M. Acinetobacter infections prevalence and frequency of the antibiotics resistance: Comparative study of intensive care units versus other hospital units. Pan Afr Med J. 2016;23:191.

45. Paton R, Miles RS, Hood J, Amyes SG, Miles RS, Amyes SG. ARI 1: $\beta$-lactamase-mediated imipenem resistance in Acinetobacter baumannii. Int J Antimicrob Agents. 1993;2:81-7.

46. Afzal-Shah M, Woodford N, Livermore DM. Characterization of OXA-25, OXA-26, and OXA-27, molecular class $D$-lactamases associated with carbapenem resistance in clinical isolates of Acinetobacter baumannii. Antimicrob Agents Chemother. 2001;45:583-8.

47. Chan MC, Chiu SK, Hsueh PR, Wang NC, Wang CC, Fang CT. Risk factors for healthcare-associated extensively drug-resistant Acinetobacter baumannii infections: A case-control study. PLoS One. 2014;9:e85973.

48. Mugnier PD, Poirel L, Naas T, Nordmann P. Worldwide dissemination of the blaOXA-23 Carbapenemase gene of Acinetobacter baumannii. Emerg Infect Dis. 2010;16:35-40.

49. Evans BA, Hamouda A, Abbasi SA, Khan FA, Amyes SGB. High prevalence of unrelated multidrug-resistant Acinetobacter baumannii isolates in Pakistani military hospitals. Int J Antimicrob Agents. 2011;37:580-1.

50. da Silva KE, Maciel WG, Croda J, Cayô R, Ramos AC, de Sales RO, Kurihara MNL, Vasconcelos NG, Gales AC, Simionatto S. A high mortality rate associated with multidrug-resistant Acinetobacter baumannii ST79 and ST25 carrying OXA-23 in a Brazilian intensive care unit. PLOS One. 2018;13:e209367.

51. El Hafa H, Nayme K, Hamzaoui N El, Maroui I, Sbiti M, Zerouali K, Timinouni M, Belhaj A. Dissemination of carbapenem-resistant Acinetobacter baumannii strains carrying the blaGES, blaNDM and blaOXA23 in Morocco. Germs. 2019;9:133-41.

52. Nordmann P. Carbapenemase-producing Enterobacteriaceae: Overview of a major public health challenge. Med Mal Infect. 2014;44:51-6.

53. Karthikeyan K, Thirunarayan MA, Krishnan P. Coexistence of blaOXA-23 with blaNDM-1 and armA in clinical isolates of Acinetobacter baumannii from India. J Antimicrob Chemother. 2010;65:2253-4.

54. Santimaleeworagun $W$, Samret $W$, Preechachuawong $P$, Kerdsin $A$, Jitwasinkul T. Emergence of co-carbapenemase genes, BLA(OXA23), BLA(VIM) AND BLA(NDM) in carbapenem-resistant Acinetobacter baumannii Clinical isolates. Southeast Asian J Trop Med Public Health. 2016;47:1001-7.

55. Nazzaro F, Fratianni F, De Martino L, Coppola R, De Feo V. Effect of essential oils on pathogenic bacteria. Pharmaceuticals (Basel). 2013;6:1451-74.

56. Saadi A, Brada M, Kouidri M, Dekkiche H, Attar F. Chemical composition and content of essential oil of Lavandula multifida from Algeria. Chem Nat Compd. 2016;52:162-4.

57. Palá-Paúl J, Brophy JJ, Goldsack RJ, Fontaniella B. Analysis of the volatile components of Lavandula canariensis (L.) Mill., a Canary Islands endemic species, growing in Australia. Biochem Syst Ecol. 2004;32:55-62.

58. Carrasco A, Ortiz-Ruiz V, Martinez-Gutierrez R, Tomas V, Tudela J. Lavandula stoechas essential oil from Spain: Aromatic profile determined by gas chromatography-mass spectrometry, antioxidant and lipoxygenase inhibitory bioactivities. Ind Crops Prod. 2015;73:16-27.

59. Badreddine BS, Olfa E, Samir D, Hnia C, Lahbib BJ. Chemical composition of Rosmarinus and Lavandula essential oils and their insecticidal effects on Orgyia trigotephras (Lepidoptera, Lymantriidae). Asian Pac J Trop Med. 2015;8:98-103.

60. Ait Said L, Zahlane K, Ghalbane I, El Messoussi S, Romane A, Cavaleiro C, Salgueiro L. Chemical composition and antibacterial activity of Lavandula coronopifolia essential oil against antibiotic-resistant bacteria. Nat Prod Res. 2015;29:582-5.

61. Vasconcelos NG, Croda J, Silva KE, Motta MLL, Maciel WG, Limiere LC, Simionatto S. Origanum vulgare L. Origanum vulgare. Essential oil inhibits the growth of carbapenem-resistant gram-negative bacteria. Rev Soc Bras Med Trop. 2019;52:e20180502.

62. Faleiro ML. The mode of antibacterial action of essential oils. Sci Against Microb Pathog Commun Curr Res Technol Adv. 2011;3:1143-56.

63. Alanis-Garza BA, Bocanegra-lbarias $P$, de Torres NW, Salazar-Aranda $R$, Mendoza-Olazarán S, Pérez-López LA, Flores-Treviño S, Garza-González E. Antimicrobial activity of essential oils-derived volatile compounds against several nosocomial pathogens including representative multidrug-resistant A. baumannii clinical isolates. J Essent Oil Res. 2018;30:341-6.

64. Bassolé IHN, Juliani HR. Essential oils in combination and their antimicrobial properties. Molecules. 2012;17:3989-4006.

65. Ultee A, Bennik MHJ, Moezelaar R. The phenolic hydroxyl group of carvacrol is essential for action against the food-borne pathogen Bacillus cereus. Appl Environ Microbiol. 2002;68:1561-8.

66. Azizan N, Mohd Said S, Zainal Abidin Z, Jantan I. Composition and antibacterial activity of the essential oils of Orthosiphon stamineus benth and Ficus deltoidea jack against pathogenic oral bacteria. Molecules. 2017;22:2135 